\title{
The Neglected Pilgrim: How Faxian's Record Was Used (and Was Not Used) in Buddhist Studies
}

\author{
MAX DEEG \\ Cardiff University \\ DeegM1@cardiff.ac.uk
}

Keywords: Faxian, Foguo ji, Buddhist Studies, Research History

DOI: https://dx.doi.org/10.15239/hijbs.02.01.02

\begin{abstract}
This paper focuses on the role of Faxian's Foguo ji, Record of the Buddhist Kingdoms (a.k.a Gaoseng Faxian zhuan) in the formation of Buddhist Studies as a discipline in the nineteenth and twentieth centuries. It will contextualize the text in the emulating historicist approach of the time which, I would claim and hope to show, led to a certain marginalization of the Record due to the typical ideological parameters inherent in the positivist and historicist interpretation of sources, such as the idea of authenticity and reliability through authorship and through the information given in the source. In this context, Faxian's Record had the disadvantage of being relatively short, restricted in terms of geographical range, and being linked to an author about whom not much was known. As a consequence, Faxian's Record was and is mostly used in a complementary way to either corroborate pieces of information from other sources-mainly from Xuanzang's Da Tang Xiyu ji which had become the main authority-hence establishing it as the earliest text of its 'genre' a historical terminus ad quem, or it has to fill gaps of information in those other sources (e.g. the report on Siṃhala/Śrī Lañkā).
\end{abstract}


espite the attention Faxian 法顯 (337-422) and his record, the Foguo ji 佛國記 (or Gaoseng Faxian zhuan 高僧法顯傳) has experienced in a little bit more than two decades by the publication of five translations into Western languages (English, German, Italian, French, Spanish), the author and his text are, without any doubt, not as well-known as the two Chinese Buddhist travellers of the Tang period, Xuanzang 玄牀 (602-664) and Yijing 義淨 (635-713), and their works. As a matter of fact, the number of translations of the Foguo ji in the last twenty years or so is at odds with the importance given to the text in scholarly literature, particularly compared with the number of citations of Xuanzang and his Record, the Da Tang Xiyu ji 大唐西域記 or Record of the Western Regions of the Great Tang. One of the reasons for this imbalance does not only lie in the brevity of Faxian's text but also in the supremacy that Xuanzang's Record attained under the influence of the historicist-positivist ideology of nineteenth century scholarship. But there are also other reasons for the intensive retranslation of the text in the nineteenth and early twentieth centuries, which James St. André has identified as a rivalry between national traditions of Oriental Studies (British vs. French) and inside of Chinese Studies (academic vs. non-academic: Giles, Legge vs. Beal; Oxford vs. Cambridge: Legge vs. Giles), and the professionalization of Chinese Studies/Sinology as an academic discipline with the attempt to correct and improve previous translations. ${ }^{1}$

The 'renaissance' of translations of the Foguo ji in the last decades may share some of the earlier reasons-for myself I would admit the digestible length of the text and the interest in the reconstruction of the history of Buddhism in Central Asia and South Asia/India-but the spread of languages already shows that there seems to have been the idea of making the text accessible to readers of different western languages like German, ${ }^{2}$ Spanish, ${ }^{3}$ Italian, ${ }^{4}$ and French, ${ }^{5}$ while the

\footnotetext{
St. André, 'Retranslation as argument', 69.

Deeg, Das Gaoseng-Faxian-Zhuan.

Bellerín, El viaje de Faxian.

4 Bianci, Faxian.

5 Drège, Faxian.
} 
slightly earlier translation by Li Rongxi was part of the broader English Tripitaka translation project funded by the Numata Foundation. ${ }^{6}$

In order to give a historical 'skeleton' for the development of the study of Faxian's text and other Chinese Buddhist travelogues in the early period of Buddhist Studies, ${ }^{7}$ I start with a list of translations made of these sources in the nineteenth century and at the beginning of the twentieth century from which it becomes clear that the Foguo $j i$ was not only the first record to be translated but also the one which was translated most frequently (Table 1 ):

TABLE 1 List of translated Chinese Buddhist travelogues. ${ }^{8}$

\begin{tabular}{|c|c|c|}
\hline Year & Scholar(s) & Title \\
\hline 1836 & Abel Rémusat & Foe-Kone-Ki \\
\hline 1848 & J. W. Laidlay & $\begin{array}{l}\text { The Pilgrimage of Fa Hian. From the } \\
\text { French Edition of the 'Foe Koue Ki' }\end{array}$ \\
\hline 1853 & Stanislas Julien & Histoire de la vie de Hiouen-Thsang \\
\hline $1857-1858$ & Stanislas Julien & Mémoires sur les contrées occidentales \\
\hline 1869 & Samuel Beal & Travels of Fah-Hian and Sung-Yun \\
\hline 1877 & Herbert A. Giles & $\begin{array}{l}\text { Fa-Hsien: A Record of the Buddhistic } \\
\text { Kingdoms }\end{array}$ \\
\hline 1884 & Samuel Beal & $\begin{array}{l}S i-Y u-K i \text { (including translations of Faxian } \\
\text { and Song Yun) }\end{array}$ \\
\hline 1886 & James Legge & A Record of Buddhistic Kingdoms \\
\hline 1888 & Samuel Beal & The Life of Himen-Tsiang \\
\hline 1894 & Édouard Chavannes & $\begin{array}{l}\text { Mémoire composé à l'époque de la Grande } \\
\text { Dynastie T'ang sur les religieux éminents }\end{array}$ \\
\hline
\end{tabular}

$6 \mathrm{Li}$, 'The Journey of the Eminent Monk Faxian'.

7 The present article is, in a way, a continuation of Deeg, 'The Historical Turn', focusing on Faxian and the Foguo ji.

8 Translations of Faxian's Foguo ji marked in grey. 


\begin{tabular}{lll}
\hline 1895 & $\begin{array}{l}\text { Sylvain Lévi \& Édouard } \\
\text { Chavannes }\end{array}$ & 'L'itinéraire d'Ou-K'ong (751-790)' \\
\hline 1896 & Takakusu Junjirō & A Record of the Buddhist Religion \\
\hline 1903 & Édouard Chavannes & 'Voyage De Song Yun' \\
\hline $1904-1905$ & Thomas Watters & On Yuan Chwang's Travels \\
\hline 1923 & Herbert A. Giles & The Travels of Fa-bsien (retranslation) \\
\hline 1938 & Walter Fuchs & Huei-ch'ao's Pilgerreise \\
\hline
\end{tabular}

As can be clearly seen, Faxian's Foguo ji has been (re)translated into English five times while Xuanzang's Da Tang Xiyu ji was only once translated into French and into English. Other texts as well have only received one translation into a Western language.

One of the deficiencies of dealing with and using the so-called pilgrims' records in general is that they rarely are seen in their cultural (spatial) and historical (time) context. By this I mean that their Chinese origin and setting is often neglected or misrepresented in favour of their assumed historical value as descriptions of Central Asia or India. The texts are often treated as if they are referring to a timeless India, somewhere between the lifetime of the Buddha and the authors' own time. The neglect of Faxian's Foguo ji as a historical source on the one hand, and its attraction as an object of translation on the other hand, reflects this insofar as the historians and archaeologists were content with Xuanzang's more detailed record and its contents for almost any period of time in the history of Indian Buddhism. Rarely did they use the two texts, authored more than two hundred years apart from each other, as means for a consequent diachronic reconstruction of Buddhist history. Normally, when Faxian does not agree with Xuanzang, the former's deficiency was referred to in order to explain the discrepancy instead of looking for the reason of such differences.

As is well known, the first translation of the Foguo ji into a Western language, ${ }^{9}$ in fact the first translation of a Chinese text at full

9 For an overview of the translation history of the text see Drège, Faxian, xx. 
length and with a commentarial apparatus since the Jesuits' activities started about two centuries earlier, was undertaken by the first chair of Sinology at the University of Paris, Abel Rémusat (1788-1832). The translation was published posthumously, 'revised, completed and enlarged by new explanations', ${ }^{10}$ by the two Orientalists Julius Heinrich Klaproth (1783-1835) and Ernest Clerc de Landresse (1800-1862). In Indological matters Rémusat, Klaproth and de Landresse did occasionally consult and were informed by the illustrious French Orientalist Eugène Burnouf (1801-1852). ${ }^{11}$ According to de Landresse's 'Introduction' Rémusat originally also wanted to produce translations of Song Yun's and Xuanzang's record, ${ }^{12}$ but considered Faxian's to be preferable in terms of importance for the historical reconstruction of Buddhism:

Fă Hian, Soung yun and Hiuan thsang have all three come through the same regions, one century apart from each other. Their records present for different and well-defined periods details, often similar and sometimes different, which, if compared and discussed, determine very important points of the religious chronology and provide many valuable pieces of information about the history and geography of Hindoustan in the 5th, 6th and 7th centuries. But the state of Buddhism and of the whole of Asia at the time of Fă Hian make the record of the latter particularly suitable and have led M. Rémusat to give it a preference over the other two which it not only deserves because of its earlier date. Then, as a matter of fact, India seems to have gone beyond its borders as it were. She was wherever Buddhism had taken hold, and nevertheless this sect, while expanding widely, still preserved its influence of fourteen centuries in the places from which it had originated. In Central India the sect had not lost, according to Fă Hian, any of its superiority over Brahmanism; if adherents of the latter had removed it from some regions the practice and the ceremonies of Buddhism, the advantages granted its followers, had for this

\footnotetext{
10 'revu, complete, et augmenté d'éclaircissements nouveaux'.

11 See de Landresse's 'Introduction' (xx).

12 De Landresse's 'Introduction', xliv.
} 
reason not stopped to exist, and Benares, nowadays so famous as an old school of wisdom of the brahmins, was populated by Samanéens (śramana). In contrast, the report of Soung yun and the one of Hiuan thsang witness the supremacy which the brahmins had finally achieved in the 6th and 7th centuries, and the correspondent decline of their adversaries in the middle, western and northern regions of Hindoustan. ${ }^{13}$

According to de Landresse, Rémusat himself had read a 'Mémoire' to the Académie d'Inscriptions in Paris, the most prominent academic institution in France, in the year 1830 during which he highlighted eight more general historical conclusions drawn from the Foguo ji:

1. Buddhism and with it Indian practices and language ${ }^{14}$ were established in Central Asia ('Tartarie centrale' = Chinese Turkestan);

2. Buddhism was dominant in the north-western regions of India (Gandhāra);

3. Central India (Gangetic plain) was the homeland of Buddhism where the Buddha had lived and preached; ${ }^{15}$

4. in Central India Buddhism was in opposition to Brahmanism and dominated it since its historical origin; ${ }^{16}$

13 De Landresse's 'Introduction', xliv (translation Deeg; I have kept the transliteration of the Chinese in the original and not transferred it into the modern standard Pinyin).

14 Rémusat calls this 'la langue Fan' (梵), by which he means both Prakrit and Sanskrit. Sykes however translates 'Sanskrit' with a rather absurd note attached (Sykes, 'Notes on the Religious, Moral, and Political State of India', 256, note 1): '[Rémusat] here necessarily means Brahmanical writings, for the Mahawanso (the Pāli chronicle Mahāvaṃsa; MD) was unknown to him.'

15 Rémusat wrongly situated Kapilavastu between Lucknow and Oudh and claimed that the Buddha was active only in regions north of the Gangā.

16 Rémusat here follows the Chinese sources and locates the Buddha in the tenth century BCE. 
5. Buddhism had reached Bengal and spread all the way to the mouth of the Gangā;

6. Buddhism had also spread to the South, into the Dekhan range, at an early point;

7. Ceylon was dominated by Buddhism;

8. Buddhist texts were available in all these regions mentioned, and they were written in either Sanskrit or Pali ${ }^{17} .{ }^{18}$

It is obvious that all these points were very well recognised and accepted in the second half of the nineteenth century, and the Foguo ji had done its service for establishing these as facts.

The Orientalist circles, particularly British scholars working in and on India, reacted immediately with reviews of the book. The Sanskritist Horace Hayman Wilson (1786-1860), the doyen of British Orientalism, while recognising it as a valuable historical source, voiced disappointment about the brevity of Faxian's account in his review read to the Royal Asiatic Society in April $1838 .{ }^{19}$ Wilson also

17 This refers to the discussion about the relation between Pali and Sanskrit at the time and is probably directed against people like Wilson who maintained that the language of Indian antiquity was Sanskrit; in contrast to Wilson's opinion Sykes, 'Notes on the Religious, Moral, and Political State of India', 258, note 1, comments on Rémusat: 'Amongst the numerous inscriptions discovered there is no one single BUDDHIST text, for centuries after Fa hian's time, in SANSKRIT.'

18 Translated into English by Sykes, 'Notes on the Religious, Moral, and Political State of India', 256, who highlights in italic the points he still considered valid at the time of his review.

19 Wilson, 'Account of the Foe Kúe Ki', 108: 'The accounts which [Faxian] gives are such as might be expected from his religious character, and, to say the truth, somewhat meagre, relating almost exclusively to the condition in which the religion of Buddha existed at the different places which he visited. Such as they are, however, they are exceedingly curious and instructive, even in this limited view, and exhibit a picture of the state of Buddhism in India, flourishing in some situations and declining in others, which, although we were not wholly unprepared to expect, yet we were hitherto without any accurate means of appreciating.' 
suggested corrections on the basis of his knowledge of Sanskrit, ${ }^{20}$ some of which are clearly missing the point, ${ }^{21}$ but some of which are, in fact, correct. ${ }^{22}$ For Wilson, the concrete value of Faxian's short record lay in the fact that it validates the Hindu sources he himself was so fond of, as

[I]t shows that many of the political divisions, of which we have intimations in the Rámáyana, Mahábhárata, Puránas and other works, such as the principalities of Kanya-Kubja, Srávasti, Kosala, Vaisáli, Magadha, Champa, Tamralipti, were then in existence, thus bearing unquestionable testimony to the authenticity of the accounts which we have of them, and to their being antecedent to the fourth century at the latest, giving us in future that date as a fixed point from which to reckon in all discussions respecting the antiquity of the language, the literature, and the history of the Hindús. ${ }^{23}$

After a completely different and laudatory review by the German Karl Friedrich Neumann (1793-1870) in 1840 which went pretty much unnoticed, ${ }^{24}$ probably because it was published in German, another British Orientalist, Colonel William Henry Sykes (17901872), Fellow of the Asiatic Society in Calcutta, spoke up against the reserved judgement of Wilson about the value of the text and its French translation. ${ }^{25}$ Sykes, who translates long passages from de

20 Wilson tried to identify the Sanskrit forms underlying the Chinese pronunciation as given by Rémusat.

21 For instance, when Wilson calls Kapilavastu the birthplace of the Buddha ('Account of the Foe Kúe Ki', 123).

22 E.g. his interpretation of banzheyuesi 般遮越師 as 'Pancavarshi' (pañcavārși[ka]) against Klaproth's pañcayukti ('Account of the Foe Kúe Ki', 113).

23 Wilson, 'Account of the Foe Kúe Ki', 140.

24 Neumann, 'Review ("Beurtheilung”) of Rémusat'. Neumann also had been the first Western scholar to discuss the Chinese Buddhist travelogues just at the time when Rémusat was working on his translation of the Foguo ji (Neumann, 'Pilgerfahrten buddhistischer Priester von China nach Indien').

25 Sykes, 'Notes on the Religious, Moral, and Political State of India'. 
Landresse's 'Introduction', uses his review of the book as the jumping board for a long and meandering discussion of all kinds of matters related to Indian history, the history of Buddhism and historical geography. ${ }^{26}$

The importance of the French translation of Faxian's text for the research of Buddhism in general, and of Indian Buddhism in particular, caused, despite the influential Wilson's reservation, the translation of Rémusat's work into English. This translation was published in 1848 by James W. Laidlay, the secretary of the Asiatic $(\mathrm{k})$ Society in Calcutta from 1846 to 1847 , and was equipped with further annotations by the translator himself, very often quite garbled and verbose, ${ }^{27}$ by Wilson and the Danish-German Indologist and professor of Bonn University Christian Lassen (1800-1876).

In his introductory 'Advertisement' Laidlay does not clearly spell out that he in fact translated Rémusat's French translation: '[ $t$ ]he original purpose of the Editor on undertaking the present version of the FO KOUE KI, was to furnish the text of the Chinese Author with only so much of the commentary as was indispensable for its easy comprehension'. Laidlay states that '[h]is chief object was to promote and assist the labours of such as are engaged in exploring the ancient monuments of India, to many of whom the original edition is not easily accessible; ...' A kind of competition with the French endeavour slips in when he continues, overestimating the British sinological capacity at his time, with the wish that,

\footnotetext{
26 For a more detailed discussion see Deeg, 'The Historical Turn'.

27 See e.g. Laidlay's long-winded elaboration about the Tibetan Buddhist canon, the great collection of 'Bauddha Theology' (The Pilgrimage of Fa Hian, 2). Some of Laidlay's comments are just wrong and false, as, for instance, his addition to Rémusat's explanation of shamen, Skt. śramana (The Pilgrimage of Fa Hian, 13): 'Shama, is a word of the Sanscrit language, signifying compassionate feeling; that is, to feel compassion for those who walk in the wrong way, to look benevolently on the world, to feel universal charity, and to renovate all creatures. This word means also, to observe oneself with the utmost diligence, or to endeavour to attain Nihility.' Laidlay claims that he took this explanation from (Karl-Eugen?) Neumann, but I was not able to trace this.
} 
The same object might be promoted could we obtain through the instrumentality of our countrymen in China versions of other Chinese authors who treat of the history and geography of India; and especially of such as, like Fa hian, Houan thsang, Song yun and Hueï sing, have actually visited this country and recorded the results of their travels. Such works are doubtless procurable with the utmost facility in every part of China, and their translation into English might be effected with the utmost facility in every part of China with the same ease at any of our Anglo-Chinese Schools or Colleges, as that of a Persian or Urdu manuscript in Calcutta. ${ }^{28}$

Laidlay's wish was not fulfilled until more than two decades later by Beal's first English translation of Faxian's and Song Yun's records without enabling British scholarship, however, to claim the wishedfor laurel wreath which went to Stanislas Julien for his translations of Xuanzang's biography and record. The fact that he actually translated the text from French does not prevent Laidlay from constantly playing down the role of the Chinese text and its French translator and commentator by pointing out mistakes of 'the lamented Remusat [sic!]' and by highlighting the value of the Indian, particularly the Pali sources for the study of Indian Antiquity. ${ }^{29} \mathrm{He}$ permanently claims British championship in the field of Oriental studies ${ }^{30}$ and downplays the achievements of French scholarship. ${ }^{31} \mathrm{He}$ even goes so

28 Laidlay, The Pilgrimage of Fa Hian, v. This sounds very much like Kittoe's suggestion from 1847 (Kittoe, 970): 'I would fain hope, that some of our brethren in China may interest themselves in the search for works in that language concerning India, and in preparing fair translations, which can alone be done by persons on the spot; ...'

29 Laidlay, 14.

30 See the note on sengqielan, Skt. sañghārāma, about which Rémusat quotes Burnouf's speculative reconstruction as 'Sangá gáram': 'Wilson, whose authority on such a subject is of great weight suggests (...) other and more probable etymologies ... in the Sanscrit word Sangálaya, or Sankhálaya; ...' (Laidlay, The Pilgrimage of Fa Hian, 19)

31 For instance, de Landresse's long 'Introduction' is not translated at all. 
far to claim a planned British 'Expedition to Chinese Tartary' (Chinese Turkestan, Xinjiang) to verify more of the first half of Faxian's record of which his 'friend Capt. Alexander Cunningham should be in command ${ }^{32}$-a project which obviously was completely and only based on Laidlay's imagination.

Only some years after Laidlay's translation the high regard for Faxian and his French translator was literally overwritten by the translations of Xuanzang's biography and his Record of the Western Regions by Stanislas Julien (1797-1873), Rémusat's successor on the chair of Sinology in Paris, published one after the other. After these translations Faxian is at best mentioned as a footnote to Xuanzang by Indologists, historians and archaeologists of South Asia.

It is a peculiar fact that the superiority of Xuanzang's reportand later of Yijing's records-as a historical source has been established not by the 'champions' of the texts, the translators and sinologists, but by Indologists, historians, archaeologists and art historians who used the translation. This led to a kind of hermeneutic circle in which the value of the Chinese source was determined by its usefulness for and compatibility with the findings, often expectations and wishful thinking, of historians or archaeologists working with South-Asian, (i.e. Indian sources) or material which then confirmed the reliability of the Chinese records, particularly of the Da Tang Xiyu ji ${ }^{33}$.

Alexander Cunningham (1814-1893), ${ }^{34}$ the 'father' or, in some respect, the 'godfather' of Indian archaeology is probably the best example for the tendency of overwriting the Foguo $j i$ by the $D a$ Tang Xiyu ji. While Cunningham originally took much of his initial inspiration for developing his method for the discovery and identification of Buddhist sites in northern India and thereby proving the historicity of Buddhism from Rémusat's translation of the Foguo ji,

\footnotetext{
32 Laidlay, The Pilgrimage of Fa Hian, 15.

33 On the use of the Chinese records for the exploration of Indian history, Buddhism and archaeology see e.g. Singh, The Discovery of Ancient India, and Ray, The Return of the Buddha.

34 On Cunningham's biography see Imam, Sir Alexander Cunningham.
} 
he switched almost exclusively to Xuanzang's record after the publication of Julien's French translation in 1857 and 1858.

In the year 1843, a letter sent by Cunningham, at that time a lieutenant and still relatively unknown in the circle of colonial antiquarians, to Sykes was published in the Journal of the Royal Asiatic Society. In this letter Cunningham declared the discovery of the ancient site or city of Samkassa (Skt. Samkāśya), ${ }^{35}$ the place where the Buddha spectacularly had come down to earth again after his three months rainy retreat in Trayastrimśa Heaven in order to preach the dharma to his deceased mother Māyā, on the basis of Faxian's description. ${ }^{36}$ At that time Cunningham suggested exactly what he would again suggest years later in his appeal to the Viceroy of India to found the Archaeological survey of India, at that time replacing Faxian by Xuanzang: '... to search out all the Buddhistical ruins in India, would be works of greatest interest and importance. With what joy and zeal would not one trace Fa Hian's route from Mathura, his first Indian station [sic!], to his embarkation for Ceylan. ${ }^{37}$

35 The Pāli forms of names were commonly used at that time partly because of the lack of the Buddhist Sanskrit sources which Hodgson had by then started to retrieve from Nepal, but also because of the emerging conviction that Pāli had been the original language of the Buddhists in India.

36 See Leoshko, Sacred Traces, 44.

37 Obviously to underline the need for such 'an undertaking of vast importance to the Indian government politically, and to the British public religiously', which Cunningham, of course, thinks to be predestined for, he comes up with two important reasons: 'To the first body it would show that India had generally been divided into numerous petty chiefships, which had invariably been the case upon every successful invasion; while, whenever she had been under one ruler, she had always repelled foreign conquest with determined resolution. To the other body it would show that Brahmanism, instead of being an unchanged and unchangeable religion which had subsisted for ages, was or comparatively modern origin, and had been constantly receiving additions and alterations; facts which prove that the establishment of the Christian religion in India must ultimately succeed.' (Cunningham, 'An Account of the Discovery of the Ruins', 246) Sykes, 'Note by Colonel Sykes', 249, in his note on Cunningham's letter, 
Interestingly, this earliest identification of a Buddhist site by Cunningham was done from the desk and not, as later, through and on a field trip: Cunningham mentions that he had sent his Munshi (native secretary) to the village of Samkassa or Samkissa; thus everything reported in Cunningham's letter is actually based on indirect information and on reconstruction with the help of the Foguo ji. In this letter Cunningham's later method is already emerging quite clearly: he starts off with the Chinese 'pilgrim's' record—in this case Faxian's but later almost exclusively Xuanzang's - and meanders into a mixture of archaeological data adjusted to the information from the Chinese text in translation or vice versa, speculations about the identity of ancient topographical names, Indian and Chinese, and modern place names-Samkassa = Samkāśya, which in this case is in fact a match-, identification of ancient and modern legends, and conclusions about the former size and importance of a site. In a direct response ('Note') to Cunningham's letter the young engineer-lieutenant was applauded by Sykes, who, as we have seen, was very fond of Faxian's record as a source for historical reconstruction: 'In the discovery of the ruins of this city [Samkāśya], ..., we have now a new proof of the honesty and good faith of the Chinese traveller, Fa Hian; ... ${ }^{38}$

What certainly helped to evaluate and establish Faxian's report as more unreliable of less important was the failure of Cunningham's 'predecessor'. In his attempt to trace Faxian's travel and the sites referred to in Bihār, ${ }^{39}$ Captain Markham Kittoe (1808-1853),

takes up a similar line of argumentation when he uses Faxian's report about Buddhas of the past as 'a fact ... of great importance to correct a mistaken opinion which generally prevails, that Sakya Buddha, who flourished in the seventh century before Christ, was the FOUNDER of the Buddhist religion', thus saving Christianity as the oldest founder religion in history.

38 Skyes, 'Note by Colonel Sykes', 248. Sykes supports Cunningham's historical argument by emphasizing that most of the sacred places of Brahmanism like Mathura, Benares, etc. were originally Buddhist and that Brahmanism had not claim of antiquity.

39 Kittoe, 'Notes on Places in the Province of Behar'. See Imam, Sir Alexander Cunningham, 53: 'Kittoe was unfortunately but poorly equipped for a duty 
appointed 'Archaeological Enquirer' in the year 1847, obviously used Laidlay's English translation of Rémusat's French before publication. ${ }^{40}$ Kittoe more or less followed the same method as Cunningham, but he was lacking the intuition and presentational skills of the latter to be able to convince his fellow antiquarians of his findings; one could even say that Kittoe was too honest and did not possess Cunningham's occasional ruthlessness to tweak the data to make them fit his conclusions or interpretations..$^{41}$ Kittoe was criticized to have made some disputable conclusions; he identified, for example, a mound near Rājgir, the ancient Rājagṛha, as the possible stūpa of the Buddha's relics built by King Ajātaśatru after the Buddha's parinirvanna, although he did not inspect the site himself but had to rely on the description of Francis Buchanan (Hamilton) $(1762-1829)^{42}$ who had visited and described the place earlier. ${ }^{43}$

Alexander Cunningham, however, came in control of the archaeological endeavour in North India and not only shaped the method of archaeological investigation but also decided the fate of the Chinese sources. In his later work he almost exclusively relied on and referred

of this kind, as is apparent from the pathetic muddle of his attempt to follow the route of Fa-hsien in Bihar.'

40 Kittoe, 'Notes on Places in the Province of Behar', 953: '... extracts from Remusat's translation of the Travels of Chy-Fa-Hian [...] obligingly furnished by our co-Secretary, Mr. J. W. Laidlay ...'

41 Where Cunningham has no problems of equating an odd Chinese transcription from a translation with an ancient or modern Indian name, Kittoe frankly admits his struggle with the Chinese names: 'We must, however, be constantly at a loss in tracing places from the curious orthography of the Chinese language, ..., and this is a sad obstacle.' (Kittoe, 'Notes on Places in the Province of Behar', 970)

42 Kittoe used the abridged version of Buchanan's report by Robert Montgomery Martin, published as volume 1 of Martin's Historical Documents of Eastern India in 1838 (Kolkata: The Asiatic Society). Buchanan's full report An Account of the Districts of Bihar and Patna in 1811-1812 was not published before 1936 by the Bihar and Orissa Research Society (Patna) in two volumes.

43 Kittoe, 'Notes on Places in the Province of Behar', 957. 
to Xuanzang's record, establishing thereby the supreme historical credibility of this source. Already in his early reports for the newly founded Archaeological Survey of India, Cunningham deplores the deficiency of the Foguo ji. ${ }^{44}$ Faxian's information is often disregarded in favour of Xuanzang's; ${ }^{45}$ rarely is the text used to corroborate the information in Xuanzang's text, ${ }^{46}$ but Cunningham sometimes uses Faxian's testimony if he needs a correction of Xuanzang's report to fit his own conclusions and identifications made on the basis of archaeological 'evidence'. ${ }^{47}$ In his widely used The Ancient Geography of India Faxian is only quoted once to support an identification based on Xuanzang ${ }^{48}$.

Cunningham's dismissive use of and judgement about the Foguo

44 Cunningham, Four Reports, 7 (on Bodhgayā): 'The holy places at Buddha-Gaya were visited between A.D. 399 and 414 by another Chinese pilgrim Fa-Hian, but his account of them is unfortunately very brief.' Cunningham, Report of Tours, 27 (on the descent of the Buddha from Trayastrimśa heaven in Saṃkāśya); 50; 137 (places around Bodhgayā); 148 (Mucilinda being blind).

45 Cunningham, 291 (on the location of an Aśokan stūpa near Kanyākubja); Cunningham 1880: 76 (on the number of stuppas dedicated to the Buddha of the past Kāśyapa: Faxian has three, while Xuanzang refers to only two).

46 Cunningham, 279 (on the location of old Kanyākubja).

47 Cunningham, 270 (distance between Saṃkāśya and Kanyākubja/Kanauj). Sometimes Faxian has to 'stand in' for Xuanzang if the latter does not deliver the information needed to confirm the existing archaeological evidence, as e.g. in case of the interpretation of the elephant capital found at Samkāśya for which Faxian reports an Aśokan pillar on which Xuanzang is silent (Cunningham, Report of Tours in the Gangetic Provinces, 22); see also Cunningham, Report of Tours in the Gangetic Provinces, 81 (description of the Jetavana in Śrāvastī); 151 (description of Pātaliputra). An example of the occasional blunder Cunningham produces when he is left alone by the translations or the notes is found in his attempt at analyzing the Chinese of Faxian's xiao gushi shan 小孤石山, 'little isolated stone mountain', probably the Indraśailaguhā near Rājag̣̣ha (Cunningham, Report of Tours in the Gangetic Provinces, 186), on which see Deeg, Das Gaoseng-FaxianZhuan, 401.

48 Cunningham, The Ancient Geography of India, 84. 
ji became standard. One or two generations later the French art historian Alfred Foucher (1865-1952) still echoed Cunningham when he wrote in his analysis of the historical geography of Gandhāra: 'This just proves that the geographical list of Fa-hien is far from being flawless, and particularly that it is infinitely less exact than that of Hiuen-tsang. ${ }^{39}$

By the end of the nineteenth century the predominance of Xuanzang over Faxian as a historically reliable source had been well established among historians, art historians and archaeologists. The widely read British colonial historian Vincent Arthur Smith (1848-1920) may be quoted as representative for this position:

The long series of Chinese Buddhist pilgrims who continued for several centuries to visit India, which they regarded as their Holy Land, began with Fa-hian (Fa-hsien), ... But the prince of pilgrims, the illustrious Hiuen Tsang, whose fame as Master of the Law still resounds through all Buddhist lands, deserves more particular notice. ... His book is a treasure-house of accurate information, indispensable to every student of Indian antiquity, and has done more than any archaeological discovery to render possible the remarkable resuscitation of lost Indian history which has recently been effected. ${ }^{50}$

The discovery of many of the sacred places in Northern India after the publication of Rémusat's French and Beal's English translation on the basis of Julien's translation of the Da Tang Xiyu ji made Faxian's record next to obsolete for the discussion of the historical geography and the history of Buddhism. Still, and somewhat astonishingly, more translations of the Foguo ji were produced. As James St. André notices, the exclusively English translations of the Foguo ji were

49 Foucher, 'Notes sur la géographie ancienne de Gandhâra', 338, note 2: 'Ceci prouve simplement que la nomenclature géographique de Fa-hien est loin d'être impeccable et, notamment, qu'elle est infiniment loins exacte que celle de Hiuen-tsang.'

50 Smith, The Early History of India, 13; repeated verbatim in the fourth edition (published 1924) of the book (Smith, The Early History of India, 14). 
less interested in reconstructing history but more concerned with the nitty-gritty of the Chinese text, trying to correct 'mistakes' made by their predecessor(s), often in a quite sharp and polemic way. ${ }^{51}$

When Samuel Beal (1825-1889) published his English translation of the Foguo ji in the year 1869 he could easily criticize some of the mistakes Rémusat ${ }^{52}$ had committed-although in some cases he did not really offer solutions and quite often he was simply wrong. ${ }^{53}$ Building on some criticism of Rémusat's translation articulated by Stanislas Julien in the preface to his Histoire de la vie de Hiwoen-Thsang [Life of Xuanzang], Beal, in a way, took over the staff of translating Faxian and other records from French to British territory. ${ }^{54}$ This British dominance lasted for a couple of decades until Édouard Chavannes and Sylvain Lévi kicked off another 'wave' of French translations of important Chinese sources such as Yijing's Da Tang qiufa gaoseng zhuan 大唐求法高僧傳, Wukong's 悟空 eighth century record and, compared with Beal's, a much improved translation of Song Yun's 宋雲 report.

When preparing his notes to his translation-meant 'to include ..., in a small space, the best information bearing on the subject'-Beal mainly relied on Julien's translation of the Da Tang Xiyu ji, Spence Hardy's notorious and ubiquitous A Manual of Buddhism, and on the first archaeological reports by Alexander Cunningham. ${ }^{55}$ In a way Beal reflects, by this selection, some of the emerging 'parameters' of

51 St. André, 'Retranslation as argument', 72.

52 Obviously, Beal's knowledge of French was rather restricted: he does not realize that Abel is Rémusat's first name but calls him Abel-Rémusat. For longer passages from the text he might have used Laidlay's English translation as he thanks Laidlay for providing him 'the English version of the Fo-koue-ki, which I could not have procured without ... assistance.' (Beal, Travels of Fab-Hian and Sung-Yun, xiii).

53 See e.g. Beal's comment on Qihuan 祇洹 ('Chi-ün'; Travels of Fab-Hian and Sung-Yun, p.ix), not recognizing that this is the Chinese transliteration of the Jetavana-vihāra in Śrāvastī.

54 Beal, Travels of Fab-Hian and Sung-Yun, vii.

55 Beal, xii. 
Buddhist Studies in the second half of the nineteenth century confirming, as it were, the hermeneutical circle to which I referred earlier:

1. the dominance of Xuanzang as an eye-witness and historical source (Julien), who is used to expound and to verify Faxian's information;

2. the authority of the Ceylonese Pāli or Theravāda tradition for the study of ancient Buddhism (Hardy), and

3. the final verification of the historical reliability of information in the Chinese text(s) through the findings of the archaeologists (Cunningham).

Beal's translation claims to improve on Rémusat's work, but in fact it is not at all free from mistakes and misinterpretations. ${ }^{56}$ Beal does not follow any recognizable system of transliteration of the Chinese, partly taking over the French spelling or inventing some transcriptions of his own. ${ }^{57}$ Although he refers to the harsh criticism launched against his translation of 1869 by Giles and Watters-however, without identifying them by name-Beal chose to reuse the text in his translation of the Da Tang Xiyu ji almost unchanged and with a reduced corpus of notes. ${ }^{58}$

Herbert Allen Giles (1845-1935), who held the second chair of Sinology at Cambridge from 1897 to his death, published a transla-

56 Beal, xii: '... M. Julien's remark, respecting the untrustworthiness of the Fokoue-ki, was not made without reason, and ..., therefore, a more careful translation of the book was to be desired.

57 See already Watters, 'Fa-Hsien and his English translators', 108.

58 Beal, $S i-Y u-K i$, xxii: 'I have not overlooked the remarks of various writers who have honoured me by noticing my little book (Buddhist Pilgrims), published in 1869. I venture, however, to hope that I have by this time established my claim to be regarded as an independent worker in this field of literature. I have not therefore quoted instances of agreement or disagreement with the writers referred to; in fact, I have purposely avoided doing so, as my object is not to write a chapter of grammar, but to contribute towards the history of a religion; but I have suffered no prejudice to interfere with the honesty of my work.' 
tion of the Foguo ji twice, once quite early in his career (1877) and once again almost half a century later and towards the end of his life (1923). He states that the purpose of his translation is to 'get at an exact grammatical analysis of the text' and not '[to elucidate] any new points in the great field of Buddhism ... ${ }^{59}$ Giles calls the text 'a meagre narrative of one of the most extraordinary journeys ever undertaken, and brought to a successful issue'. ${ }^{60}$ While he held Rémusat's scholarship in esteem he considered the published product spoiled by Klaproth and de Landresse. ${ }^{61}$ But Giles' aggressive criticism is mainly directed against his compatriot Beal whom he accuses of many mistakes, ${ }^{62}$ of having 'been unqualified for the task he undertook', ${ }^{63}$ and of plagiarism by using the commentarial notes from Rémusat's translation without acknowledging it. ${ }^{64}$

Giles' re-translation of 1923 omits all notes, ${ }^{65}$ integrates some

\section{Giles, Record of the Buddhistic Kingdoms, ii.}

60 Giles, i.

61 Giles, i: 'This work was translated into French by Rémusat, but he did not live to superintend its publication. He had, in fact, only revised about one half, that half being accompanied by valuable and exhaustive notes. In this state it fell-we are almost saying, among thieves — into the hands of Klaproth, who, with the slender assistance of Landresse and his own very considerable aplomb, managed to fill up the blanks of the latter portion, add some bulky notes after the manner, but lacking the scholarship, of Rémusat, and generally patch up the whole in a form presentable to the public.'

62 Giles, i, and in numerous footnotes.

63 Giles, ii.

64 Giles, ii: '[Beal] certainly corrected a great many of Rémusat's blunders, speaking somewhat unctuously of the "looseness" of the French version, but we could not dismiss from our minds the unpleasant suspicion that Mr. Beal had drawn upon the valuable notes to that despised volume to a greater extent than he was frank enough to acknowledge.' It is funny to see that when Giles uses Beal's explanations and notes he refers to him as 'Beal', while when launching his philological criticism against him he uses the sarcastic 'Mr. Beal'.

${ }^{65}$ Giles, The Travels of Fa-bsien: 'While giving, so far as possible, a strictly literal and accurate rendering, I have attempted at the same time to make the narra- 
new knowledge from the field of historical geography, ${ }^{66}$ but otherwise closely follows his own previous translation. In his 'Bibliographical Notes' Giles repeats his high opinion of Rémusat's translation, ${ }^{67}$ reiterates his dismissive comment on Beal, ${ }^{68}$ and adds one on his former colleague in 'that other institution' (Oxford), James Legge without mentioning, ${ }^{69}$ however, the harsh critique launched against his own first translation by Thomas Watters (see below). The translation, sometimes quoted in secondary literature probably because of its plain presentation of the text, has rather suffered from the complete lack of annotations. The reader has the feeling that Giles, for instance, was looking desperately for an opportunity to utter some strange remarks on the Trinity in Christianity and in Buddhism (triratna) in his 'Introduction' to the translation. ${ }^{70}$

In a series of articles published in various fascicles of The China Review in the years 1879 and 1880 Thomas Watters (1940-1901), the author of the only extensive commentary on Xuanzang's $\mathrm{Da}$ Tang Xiyu ji in a Western language, rehabilitated the Foguo ji and its

tive appeal to the general reader by the omission of foot-notes which most people dislike, and of references to authorities which are usually altogether ignored. Thus, it is hoped that there will be no check to the enjoyment of the reader as he travels along with Fa-hsien on his stupendous journey.'

66 Giles, xiii, explicitly mentions Chavannes, Stein and Kurita.

67 Giles, viii: 'The first translation of the Record was in French; it was begun by Rémusat and finished by Klaproth and Landresse. It was a brilliant performance, considering the difficulty of the text and the date, ... but it ran up to 424 large 4to pages, mostly consisting of elaborate notes, and of course failed to attract a wide circle of readers.'

${ }_{68}$ Giles, viii: 'In 1869, the Rev. S. Beal produced an English translation, really of Rémusat's work, in which he reproduced all Rémusat's mistakes while adding more of his own.'

69 Giles, viii: 'In 1886, Dr Legge published a fresh translation, in which he borrowed largely, without acknowledgement, from my corrections of Beal, and managed to contribute not a few mistakes of his own.'

70 Giles, vi. 
French translator:

The Fo-kuo-chi, or Record of Buddhistic Kingdoms, by Fa-hsien, is rightly considered as a most valuable book with reference to the earliest history of Buddhism. A French translation of it was published in 1836, and this was afterwards translated into English. ... The publication of this treatise was an event of great importance in the history of Buddhist learning in Europe. ${ }^{71}$

At the same time Watters launches an almost vicious attack on both Beal's and Giles' translations. Watters' general verdict on both English translations is a devastating one:

Everyone who has read the 'Travels of Fah-hian' [Beal] and the 'Record of the Buddhistic Kingdoms' [Giles] must own that neither of these can be used as a work of authority. Neither can be said to be a great improvement on Rémusat's treatise, as Mr Beal, not to mention other defects, had little knowledge of Chinese and Mr Giles had less knowledge of Buddhism. ${ }^{72}$

The translation of the Foguo ji is the only work on Buddhism by the Oxford chair of Sinology and famous editor and translator of the Chinese Classics James Legge (1815-1897). ${ }^{73}$ The question why Legge chose the Foguo ji for his 'Buddhist Experiment' is not directly answered by Legge; he only points out that he had been working on this text for a couple of year. ${ }^{74}$ Norman Girard has suggested that it was Legge's biographical affinity with the topic of the texts which attracted him to it:

71 Watters, 'Fa-Hsien and his English translators', 107.

72 Watters, 107. In a way, Beal gets away with less slapping and Giles has to take the heaviest blow: 'But as Mr Giles was evidently not acquainted with even the beggarly elements of Buddhism, he made some laughable and some serious mistakes in his own translation.'

73 See Girard, The Victorian Translation of China, 408.

74 Legge, A Record of Buddhistic Kingdoms, xi. 
Fa Xian's [sic!] Foguo ji, as a transcultural narrative of a pilgrim cleric and missionary-translator, mirrors in a way Legge's own transformative journey as a conscientious missionary agent and as a faithful scholar. ... Fa Xian and Legge shared a dutiful devotion to 'simple straightforwardness' when it came to the description of other nations and religions. ${ }^{75}$

In his 'Preface' Legge refers to Watters' review articles and regrets that Watter's himself had not done a complete translation. ${ }^{76}$ For his translation Legge used, as he emphasizes, a copy from the Japanese Chinese Buddhist canon sent to him by the former Oxford student Bunyiu Nanjio (Nanjō Bunyū 南条文雄) which he calls Corean ${ }^{77}-$ referring to the Koryŏ/Gaoli 高麗 canon-and which is reproduced after the translated text. For Buddhist matters Legge had access to the early version of Ernst Johan Eitel's (1838-1908) Handbook of Chinese Buddhism, ${ }^{78}$ and used Spence Hardy's Eastern Monasticism and Manual of Buddhism as well as Rhys-Davids' Buddhism and translations from the Pali canon in Max Müller's Sacred Books of the East for other Buddhist matters. ${ }^{79}$ The translation is equipped with

75 Girard, The Victorian Translation of China, 411. It is very likely that Legge's acquaintance with his Oxford colleague Max Müller and his Japanese students had some influence on Legge's decision to go astray into Buddhological territory.

76 Legge, A Record of Buddhistic Kingdoms, xii: 'I have regretted that Mr. Watters, while reviewing others, did not himself write out and publish a whole version of Fâ-hien's narrative. If he had done so, I should probably have thought that, on the whole, nothing more remained to be done for the distinguished Chinese pilgrim in the way of translation.'

77 Legge, xi, xiv, and 4.

78 Eitel, Handbook for the Student of Chinese Buddhism. This was the predecessor of Eitel's enlarged and widely used Handbook of Chinese. Eitel's book certainly proved to be useful for Legge's task since it heavily draws on Faxian's and Xuanzang's records: see Eitel, Handbook for the Student of Chinese Buddhism, 'Preface', 3.

79 It is reflecting the unpreparedness of the great Sinologist for his task that 
rather lengthy notes which sometimes are just wrong, ${ }^{80}$ or sometimes go astray in the apologetic way of a former Scottish Nonconformist missionary and minister. ${ }^{81}$ Since Legge chose, as in his other works, to use a kind of idiosyncratic form of transcription of Cantonese rather than Mandarin it is rather difficult to identify the names and terms which he uses in his translation. ${ }^{82}$ All in all, the translation is a not so successful attempt of a Confucian scholar to cope with a Buddhist text, ${ }^{83}$ and has, as far as I can see, probably been the least quoted of all the translations.

With all this quibbling and accusing each other of serious mistakes and errors the English translators certainly have contributed

in his notes Legge rather quotes from these secondary sources, based on the Pāli or Theravāda tradition - which at that time starts being considered more original and authentic than other traditions - than referring to Chinese Buddhist texts or Burnouf's and other scholars' works based on the so-called 'Northern Buddhism'.

80 See e.g. Legge, A Record of Buddhistic Kingdoms, 33, note 3: 'On his attaining to nirvâna Śâkyamuni became the Buddha, ...'

81 See his somewhat abrupt discussion of the number of Buddhists in the world in the 'Introduction' where he takes the stance that all the numbers given are exaggerated (see Girard, The Victorian Translation of China, 412). Also, for example, his note on the term seng: 'So ["monk"] I prefer to translate the character (săng) rather than by "priests". Even in Christianity, beyond the priestly privilege which belongs to all believers, I object to the ministers of any denomination calling themselves or being called "priests;" and much more is the name inapplicable to the śramanas or bhikshus of Buddhism which acknowledges no God in the universe, no soul in man, and has no services of sacrifice or prayer in its worship.' (Legge, A Record of Buddhistic Kingdoms, 13, note 2).

82 Legge, A Record of Buddhistic Kingdoms, xii: 'In transliterating the names of Chinese characters I have generally followed the spelling of Morrison rather than the Pekinese, which is now in vogue. We cannot tell exactly what the pronunciation of them was, about fifteen hundred years ago, in the time of Fâ-hien; but the southern mandarin must be a shade nearer to it than that of Peking at the present day.'

83 The reaction in the reviews reflect the same reservation: see Girard, The Victorian Translation of China, 413. 
to a certain degree of uncertainty as to which translation to use and indirectly supported the high regard in which Xuanzang was held by the scholarly readers and users of the texts. ${ }^{84}$ The fact that there was only one translation into English of the Da Tang Xiyu ji-in fact, until Li Rongxi published his work in the year 1996 -, although it had been made by the so heavily critiqued Samuel Beal, must have cemented the outsider's view that Xuanzang was more reliable than his predecessor Faxian.

Leaving aside Giles' 're-translation', no real work has been done on Faxian and his text ${ }^{85}$ for more than a century outside of China or Japan $^{86}$ since the publication of Legge's translation. If Western scholars chose to quote from the Foguo ji they, randomly and without any particular and sound reason for their preference, either went for Beal, Giles or Legge. It took more than a hundred years until the text was retranslated into English, this time by a Chinese scholar, Li Rongxi. It seems that, since then, Faxian and his text have re-emerged from the abyss of Western negligence and have been made, once more, the object of serious translation work (see above) and research. ${ }^{87}$

${ }^{84}$ The 'confusion' about which translation to choose began already much earlier; see Cunningham, Report of Tours in the Gangetic Provinces, 24, who quotes the same passage on Saṃkāśya in the version of Beal and Laidlay's 'translation'.

85 In fact, the only scholarly work engaging directly with aspects of Faxian's and the other Buddhist travellers' texts, aside from notes and remarks in various publications by Paul Pelliot, seems to be Barrett, 'Exploratory Observations on Some Weeping Pilgrims'.

86 In Japan and in China research on Faxian and other travelogues has continued, very much unnoticed by Western scholarship, only to mention on Faxian the works of Adachi Kiroku 足立喜六, Nagasawa Kazutoshi 長澤和俊, Zhang Xun 章巽, etc.

87 See e.g. Meisig, 'Auf den Spuren des Dharma'; Hu-von Hinüber, 'Chinesische buddhistische Indienpilger als Grenzgänger'; idem, 'Faxian’s (法顯 342-423) Perception of India'; idem, 'The Case of the Missing Author'; idem, 'Faxian's (法顯) Worship of Guanshiyin (觀世音) and the Lotus Sūtra of 286 (正法華經)'; idem, 'Grenzerfahrungen der chinesischen Indienpilger im 5. Jahrhundert'; and Deeg, 'Abhayagirivihāra - Geschichte und “Geschichte” eines ceylonesischen Klosters'. 


\section{Bibliography}

Barrett, Timothy H. 'Exploratory Observations on Some Weeping Pilgrims'. In The Buddhist Forum, Volume 1 (Seminar Papers 1987-1988), edited by Tadeusz Skorupski, 99-110. London: School of Oriental and African Studies, University of London, 1990.

Beal, Samuel. Travels of Fah-Hian and Sung-Yun. Buddhist Pilgrims from China to India (400 A.D. and 518 A.D.). London: Trübner and Co., 1869.

- - - Si-Yu-Ki. Buddhist Records of the Western World. London: Kegan Paul, Trench, Trübner \& Co., 1884.

Bellerín, Laureano Ramírez. El viaje de Faxian: Edición, tradución y notas. Relatio del peregrinaje de un monje chino a los reinos budistas de Asia Central y la India en el siglo $V$. [The life of Faxian : Compilation, translation and notes. An account of a pilgrimage of a Chinese monk to the Buddhist Kingdoms of Central Asia and India in the fifth century]. Madrid: La Esfera de los Libros, 2010.

Bianchi, Ester. Faxian: un pellegrino cinese nell'India del V secolo, con traduzione del diario di viaggio Gaoseng Faxian zhuan [Faxian: a Chinese pilgrim in India in the fifth century, with a translation of the travel diary Gaoseng Faxian Zhuan]. Perugia: Morlacchi Editore, 2013.

Cunningham, Alexander. 'An Account of the Discovery of the Ruins of the Buddhist City of Samkassa (Letter to Colonel Sykes, FRS)'. Journal of the Royal Asiatic Society 7 (1843): 241-47.

_-_. Four Reports Made during the Years 1862, 1863, 1864, 1865. Simla: Government Central Press, 1871 (Archaeological Survey of India, Volume I).

- - - The Ancient Geography of India, I. The Buddhist Period Including the Campaigns of Alexander, and the Travels of HwenThsang. London: Trübner and Co., 1871.

- - . Report of Tours in the Gangetic Provinces from Badaon to Bibar, in 1875-76 and 1877-78 (Archaeological Survey of India, Volume XI). Calcutta: Office of the Superintendent of Government Printing, 1880. 
Deeg, Max. Das Gaoseng-Faxian-Zhuan als religionsgeschichtliche Quelle: der älteste Bericht eines chinesischen buddhistischen Pilgermönchs über seine Reise nach Indien mit Übersetzung des Textes [The Gaoseng Faxian zhuan as a Source for the History of Religion: The Oldest Record of a Chinese Buddhist Pilgrim Monk on his Journey to India with Translation of the Text]. Studies in Oriental Religions 52. Wiesbaden: Otto Harrassowitz, 2005.

- _ . 'Abhayagirivihāra - Geschichte und "Geschichte" eines ceylonesischen Klosters' [Abhayagirivihāra: History and Story of a Sri Lankan Monastery]. In Mauss - Buddhismus - Devianz. Festschrift für Heinz Mürmel zum 65. Geburtstag [Mauss Buddhism - Deviance: Festschrift Commemorating the 65th Birthday of Heinz Mürme], edited by Thomas Hase, Johannes Graul, Katharina Neef, and Judith Zimmermann, 137-53. Marburg: diagonal-Verlag, 2009.

- - - 'The Historical Turn: How Chinese Buddhist Travelogues Changed Western Perception of Buddhism'. Hualin International Journal of Buddbist Studies 1, no. 1 (2018): 43-75.

Drège, Jean-Pierre. Faxian, Mémoire sur les pays bouddhistes. Texte établi, traduit et annoté. Paris: Les Belles Lettres, 2013.

Eitel, Johann Ernst. Handbook for the Student of Chinese Buddhism. London: Trübner \& Co, 1870.

- - - Hand-book of Chinese Buddhism, being a Sanskrit-Chinese dictionary, with vocabularies of Buddhist terms in Pali, Singhalese, Siamese, Burmesi, Tibetan, Mongolian and Japanese. Hongkong: Lane, Crawford \& co., 1888.

Foucher, Alfred. 'Notes sur la géographie ancienne de Gandhâra (Commentaire à un chapitre de Hiuen-Tsang)' [Notes on the ancient geography of Ghandara (Commentary on a chapter of Hiuen-Tsang)]. Bulletin de l'École Française d'Extrême-Orient [Bulletin of the French Academy of the Far East] 1 (1901): 322-69.

Giles, Herbert A. Record of the Buddhistic Kingdoms. London, Shanghai: Trübner \& Co., Kelly \& Walsh, 1877.

- - - The Travels of Fa-hsien (399-414 A.D.), or Record of the Buddhistic Kingdoms. Cambridge: Cambridge University Press, 1923. 
Girard, Norman J. The Victorian Translation of China: James Legge Oriental Pilgrimage. Berkeley: University of California Press, 2002.

Hu-von Hinüber, Haiyan. 'Chinesische buddhistische Indienpilger als Grenzgänger: Ansätze zu einer neuen Deutung on Faxians Reisebericht' [Chinese Buddhist Pilgrims to India as Border Crossers. Attempts at a New Interpretation of Faxian's Travelogue]. In From Turfan to Ajanta: Festschrift for Dieter Schlingloff on Occasion of his Eightieth Birthday, edited by Eli Franco \& Monika Zin, 413-34. Lumbini: Lumbini International Research Institute, 2010.

- - _. 'Faxian's (法顯 342-423) Perception of India: Some New Interpretations of His Foguo ji 佛國記'. Annual Report of the International Research Institute for Advanced Buddhology at Soka University for the Academic Year 2010 issue (2011): 223-47.

- _ - 'The Case of the Missing Author: Who wrote the anonymous epilogue of Faxian's Foguoji?' Annual Report of the International Research Institute for Advanced Buddhology at Soka University for the Academic Year 2012 (2013): 307-14.

- - C. 'Faxian's (法顯) Worship of Guanshiyin (觀世音) and the Lotus Sütra of 286 (正法華經)'. Annual Report of the International Research Institute for Advanced Buddhology at Soka University for the Academic Year 2014 issue (2015): 311-19.

_-_. 'Grenzerfahrungen der chinesischen Indienpilger im 5. Jahrhundert' [Border Experience of the Chinese Pilgrims to India in the 5th Century]. In Der Weise gebt leise 智者悄然地 離去. Im Gedenken an den Begründer der Freiburger Sinologie, Professor Dr. Peter Greiner [The Wise Walks Away Silently. In Commemoration of the Founder of Sinology at Freiburg University, Professor Dr. Peter Greiner], edited by H. von Senger and H. Hu-von Hinüber, 15-32. Wiesbaden: Otto Harrassowitz, 2016.

Imam, Abu. Sir Alexander Cunningham and the Beginnings of Indian Archaeology. Dacca: Asiatic Society of Pakistan, 1966.

Kittoe, Markham. 'Notes on Places in the Province of Behar, supposed to be those described by Chy-Fa-Hian, the Chinese Buddhist Priest, who made a pilgrimage to India, at the close of 
the fourth century A.D.'. Journal of the Asiatic Society of Bengal 16 (1847): 953-70.

Laidlay, J. W. The Pilgrimage of Fa Hian. From the French Edition of the 'Foe Kone Ki' of MM. Rémusat, Klaproth, $G$ Landresse with Additional Notes $\sigma^{2}$ Illustrations. Calcutta: Baptist Mission Press, 1848.

Legge, James. A Record of Buddhistic Kingdoms: Being an Account by the Chinese Monk Fâ-Hien of His Travels in India and Ceylon (A.D. 399-414) in Search of the Buddhist Books of Discipline. Oxford: Clarendon Press, 1886.

Leoshko, Janice. Sacred Traces: British Explorations of Buddhism in South Asia. Aldershot, Burlington: Ashgate, 2003.

Li Rongxi. 'The Journey of the Eminent Monk Faxian'. In Lives of Great Monks and Nuns, edited by Li Rongxi, et al., 161-214. Berkeley: Numata Center for Buddhist Translation and Research, 2002.

Meisig, Marion. 'Auf den Spuren des Dharma. Einblicke in die Psyche des Pilgers Făxiăn' [On the Traces of the Dharma: Insights into the Psyche of the Pilgrim Faxian]. In Chinesische Religion und Philosophie: Konfuzianismus, Mobismus, Daoismus, Buddhismus - Grundlagen und Einblicke [Chinese Religion and Philosophy: Confucianism, Mohism, Daoism, Buddhism - Basic Ideas and Insights], edited by Konrad Meisig, 123-40. Wiesbaden: Otto Harrassowitz, 2005.

Neumann, Karl Eugen. 'Pilgerfahrten buddhistischer Priester von China nach Indien' [Pilgrimages of Buddhist Priests from China to India]. Historisch-Theologische Zeitschrift [HistoricalTheological Journal] 3, no. 11 (1833): 114-77.

_-_. 'Review ("Beurtheilung”) of Rémusat 1836'. Zeitschrift für die Kunde des Morgenlandes 3 (1840): 105-51.

Ray, Himanshu Prabha. The Return of the Buddha: Ancient Symbols for a New Nation. New Delhi: Routledge, 2014.

Rémusat, Abel. Foe-Kone-Ki, ou Relations des Royaumes Bouddhiques, ou Voyages des Royaumes Bouddhiques: Voyage dans la Tartarie, dans l'Afghanistan et dans l'Inde, exécuté, à la fin du IVe Siècle, par Chy Fa Hian (traduit du Chinois et commenté par M. Abel Rémusat. Ouvrage Posthume, revu, complété, et augmenté 
d'éclaircissements nouveaux par MM. Klapproth et Landresse). Paris: Imprimerie Royal, 1836. (translated into English as Laidlay 1848 [see above]).

Singh, Upinder. The Discovery of Ancient India: Early Archaeologists and the Beginnings of Archaeology. Delhi: Permanent Black, 2004.

Smith, Vincent Arthur. The Early History of India: From 600 B.C. to the Mubammadan Conquest, Including the Invasion of Alexander the Great. London: The Grollier Society Publishers, 1906.

- - . The Early History of India. From 600 B.C. to the Mubammadan Conquest, Including the Invasion of Alexander the Great. 4th and revised edition. Oxford: Clarendon Press, 1924.

St. André, James. 'Retranslation as argument: canon formation, professionalization, and rivalry in 19 th century Sinological translation.' Cadernos de Tradução [Translation Notebooks] 11, no. 19 (2003): 59-93.

Sykes, William Henry. 'Notes on the Religious, Moral, and Political State of India before the Mahomedan Invasion, chiefly founded on the Travels of the Chinese Buddhist Priest Fa Hian in India, A.D. 399, and on the Commentaries of Messrs. Rémusat, Klaproth, Burnouf, and Landresse.' Journal of the Royal Asiatic Society of Great Britain and Ireland 6, no. 2 (1841): 248-484.

- - - 'Note by Colonel Sykes'. Journal of the Royal Asiatic Society 7 (1843): 247-49.

Watters, Thomas. 'Fa-Hsien and his English translators'. The China Review 8, no.1, 8, no. 3 , 8, no. 4, 8, no. 5, 8, no. 6, 9, no. 1 (18791880): 107-16, et. subs.

Wilson, Horace Hayman. 'Account of the Foe Kúe Ki, or Travels of Fa Hian in India'. Journal of the Royal Asiatic Society of Great Britain and Ireland 5, no. 1 (1839): 108-40. 